\title{
Behaviors of the SPT Teacher: Real Authority or Simple Autonomy
}

\author{
Paulin Mandoumou ${ }^{1,2 *}$, Sylvain David Mabassa',2, Aristide Ewamela1,2, \\ Portejoie Jean Aimée Tsiama1, Hubert César Mviri², Joachim Bongbele 1,2 \\ ${ }^{1}$ Institute on Higher Physical Education and Sports, University Marien Ngouabi, Brazzaville, Cango \\ ${ }^{2}$ Chaire Unesco Sciences Education, Chaire Unesco Sciences Education, University Marien Ngouabi, \\ Brazzaville, Cango \\ Email: *mandpaulin@yahoo.fr,dmabassa@gmail.com,be_aristide2088@yahoo.fr, \\ joachim.bongbele@umng.fr
}

Received 23 November 2015; accepted 22 January 2016; published 26 January 2016

Copyright (C) 2016 by authors and Scientific Research Publishing Inc.

This work is licensed under the Creative Commons Attribution International License (CC BY).

http://creativecommons.org/licenses/by/4.0/

(c) (i) Open Access

\begin{abstract}
The purpose of this study was to analyze the real behaviors of SPT teachers which help understand the communications supporting their authority and pupils' autonomy subjected to training in a cycle of 10 lessons. The study was carried out with 280 pupils and 8 teachers. The results show that the SPT teachers' style of teaching gathers $80 \%$ of behaviors, and then only $20 \%$ are reserved to support the pupils' autonomy. It appears that the SPT teachers in a dominating way use the organizational communications and technical feedbacks to control pupils. In the same way, they essentially use questioning, cheering and congratulations to support their autonomy.
\end{abstract}

\section{Keywords}

SPT, Teachers' Authority, Pupils' Autonomy, Feedbacks

\section{Introduction}

The teacher is a partner implied and privileged in the educational system. His behavior has a determining place in the teacher-pupil relationship. Several works concerned the role of the behaviors developed by the teacher in the social interactions in general and the school interactions in particular [1]-[3]. This work shows that in the scholar environment, the teachers' behavior towards the pupil is dependent on several factors, among other things, the social role of the teacher, his role, his personal characteristic and these of the pupil in the classroom. Teachers and pupils thus develop jointly positive behaviors to one another. If such is the case, it is probable that the teacher-pu- pil relationship involves one lived positive school. As the specific characteristics to the teachers

\footnotetext{
*Corresponding author.
} 
are factors which cause the opposition of the specific behaviors, it is possible that behaviors be different towards boys and girls. In addition, the climate of teaching-learning takes into account of the notional contents taught by the SPT teacher, from interactions among pupil, didactical material, sporting installations, the duration of the activity and characteristics of the environment. As one can note it, we can say with Good and Brophy [4] that the climate of teaching-learning accompanies the didactical action by the teacher through the behaviors that implements, strategies of teaching which it proposes, nature of the interactions with pupils, training situations that he arranges, feedback that he develops. Thus, taking account the specificity of the SPT in which the teachers very frequently see their pupils in action, the teachers' behaviors of SPT should be more precise than the selves-realizers, contrary to other scholar disciplines. Indeed, the teacher of SPT has more possibilities of regularly evaluating driving competences of the pupils, and thus more chance to base his behaviors on objective variables. For this reason, it seems possible that the teachers' behaviors of SPT are largely precise and that consequently their effects of selves-realizers are relatively weak.

\section{Methodology}

280 subjects including 160 boys, 120 girls and 8 SPT teachers ( 5 men and 3 women) were retained. Subjects resulted on average of $13.6 \pm 0.59$ years old and from 8 classes at a rate of 35 pupils per class. Our choice was made on the various classes aiming in increasing the probability that teachers did not have experience on the former lesson with the latter ones. Teachers were on average of $32.86 \pm 8.92$ years old and had track records oscillating between 6 to 15 years.

\subsection{Procedure}

The study was led on the cycles of physical-activities and sporting (APS) of ten (10) lessons (the first lesson and behind lesson were devoted to evaluations and were not taken into account). Before the experiments, it was specified with teachers, pupils, and parents of pupils like to the scholar administration that the sequences of teaching would be filmed for needs and study. This manner of making would guarantee the anonymity of the participants. The interactions teachers-pupils were recorded uninterrupted during eight (8) lessons of training one hour each one using a numerical video camera allowing a precise recording of the contents, communications which are synchronized with the image.

\subsection{Measurements}

\subsubsection{Identification of the Interactions Teacher-Pupils}

Only verbal communications of the teacher were recorded. The verbal interactions between teachers and pupils were notched in the card of observation starting from the video sequences carried out in SPT.

\subsubsection{Prototype of the Operational Behaviors and Type of Communications Observed}

It is the model of Desrosiers et al. [5] which retained. Thus seven (7) verbal communications were retained in accordance with the table hereafter.

1-Communications of an organizational order:

2-Technical or tactical feedbacks

-Supporting autonomy

-Supporting the authority

3-Questions

-Supporting autonomy

-Supporting the authority
-Frequency of the suggestions coming from technical or tactical order which encourage pupils to take initiatives to solve its nervous problems in an independent way.

-Frequency of the technical or tactical directives which impose the realization of a particular nervous skill to pupil.

-Frequency of the questions which offer a choice to the pupil.

-Frequency of the directives posed in the form of question.

\footnotetext{
"That you could test various manners to cross this obstacle and to see which is most effective”.

"Tend your arm, that made 10 time that I say it to you".
}

"Which is the exercise with which you would like to start?”

“What have I?” 


\begin{tabular}{|c|c|c|}
\hline \multicolumn{3}{|l|}{ Continued } \\
\hline 4-Congratulations & $\begin{array}{l}\text {-Frequency of verbal approvals intended to } \\
\text { reinforce the behavior of the pupil. }\end{array}$ & "That is well, cheer!" \\
\hline 5-Encoura-gements & $\begin{array}{l}\text {-Frequency of the communications } \\
\text { intended to instigate the } \\
\text { activity of the pupil. }\end{array}$ & $\begin{array}{l}\text { "That is there you included/understood, } \\
\text { continuous!”. }\end{array}$ \\
\hline 6-Negative & communications relatives to & \\
\hline -Social behaviors of the pupil & $\begin{array}{l}\text {-Frequency of the directives used to } \\
\text { restore the discipline in the class. }\end{array}$ & “Keep silent Paul!” \\
\hline School work of the pupil & $\begin{array}{l}\text {-Frequency of the Directives which } \\
\text { aim at underlining the } \\
\text { lack of effort of the pupil and } \\
\text { which can be sarcastic }\end{array}$ & $\begin{array}{l}\text { "Do not make any too especially, you } \\
\text { would be likely to use the counsels?" }\end{array}$ \\
\hline 7-Criticisms & $\begin{array}{l}\text {-Frequency of the communications } \\
\text { wounding or humiliating for the pupil. }\end{array}$ & "You are really good with nothing!”. \\
\hline
\end{tabular}

Work of Carlier et al. [6] made it possible to select the behaviors of the teacher addressing himself to only one individual.

\subsection{Treatment of the Data}

The calculation of the arithmetic mean, the variance and the standard deviation estimated with the sample were used. The tests of Student and Fischer-Snedecor made it possible to compare and check the variables evaluated in several groups. The variance analysis was also used.

\section{Results}

The various results obtained are presented in Tables 1-3.

\section{Discussion}

The results of Table 1 show a highly significant difference between the organizational communications of orders supporting the authority and autonomy $(18.27 \pm 1.42$ vs. $1.99 \pm 0.79 ; \mathrm{p}<0.001)$. The fact of supporting his teaching by authority is undoubtedly justified by the weight of the school context (the pressure relating to success of the pupils to examinations, plethoric classes, effective working time) which exerts a pressure on the teacher and symbolizes a "ground" which improves the expression of behaviors supporting authority. In the same way, the oppressive school context seems to push the SPT teachers towards the authoritative strategies and often provides illusion to be effective. Lastly, specifical characteristics to the teacher, such as his believes on motivation, his designs of the "good" teacher, or his hopes with regard towards pupils likely to harden this spontaneous inclination towards control. In addition we also obtained a significant difference of technical feedbacks supporting teacher's authority versus autonomy $(21.77 \pm 5.57$ versus $1.02 \pm 0.70 ; \mathrm{p}<0.05)$. It is probable that the confrontation of the teacher to the turbulent pupils, the working time has been reduced because of the extra muro courses can justify the feedbacks supporting the authority of the teacher. He was also shown in same Table 1 that all the teachers use primarily the organizational communications of nature and the technical feedbacks to control their pupils. Here, we can say with Reeve [7] that the initial training of the teachers of SPT can justify this state of business. Indeed, according to Reeve initial training fixes the teacher on the sciences management of the class and on the contents of the impossible teaching to circumvent of the discipline. However, the results of Table 1 concerning the interactions relating to the questions of authority showed a highly significant difference between the verbal communications supporting the authority and autonomy ( $4.75 \pm 2.02$ versus $2.36 \pm 1.68$; $\mathrm{p}<0.001$ ). These results prove here that the first training form of the expression of the SPT teacher. It acts thus as affirms it Deci [8] to question the pupil in order to cause at his place a research activity without him to give "the done everything" solution. The SPT teacher in his practices guides the pupil towards the correct demonstrations and driving images to implement. About the results of Table 1 always on the style of teaching, one notices a highly significant difference between the styles in teaching authority versus autonomy 
Table 1. Presentation of the various behaviors of the SPT teacher concerning verbal communications supporting authority and autonomy.

\begin{tabular}{|c|c|c|c|c|}
\hline & Authority & Authority & \multirow{2}{*}{$\mathrm{t}$} & \multirow{2}{*}{$\mathrm{p}$} \\
\hline & $\mathrm{X} \pm \mathrm{AND}$ & $\mathrm{X} \pm \mathrm{AND}$ & & \\
\hline $\begin{array}{c}\text { Organizational } \\
\text { Communications of orders }\end{array}$ & $18.27 \pm 1.42$ & $2.99 \pm 0.79$ & 3.47 & $\mathrm{~S}^{* * *}(<0.001)$ \\
\hline Technical feedbacks & $21.77 \pm 5.57$ & $1.02 \pm 0.70$ & 1.99 & $\mathrm{~S}^{*}(<0.05)$ \\
\hline $\begin{array}{l}\text { Relative interactions } \\
\text { To the questions }\end{array}$ & $4.75 \pm 2.02$ & $2.36 \pm 1.68$ & 6.28 & $\mathrm{~S}^{* * * *}(<0.001)$ \\
\hline Teaching styles & $56.45 \pm 8.55$ & $20.41 \pm 4.11$ & 3.62 & $\mathrm{~S}^{* * *}(<0.001)$ \\
\hline
\end{tabular}

Table 2. Evaluation of the interactions relating to the congratulations, encouragements and criticisms.

\begin{tabular}{ccccc}
\hline & Congratulations & Encouragements & Criticisms & $\mathrm{P}$ \\
\cline { 2 - 4 } & $\mathrm{X} \pm$ AND & $\mathrm{X} \pm$ AND & $\mathrm{X} \pm$ AND & $(<0.001)$ \\
\hline Interactions types & $3.28 \pm 1.36$ & $5.75 \pm 1.42$ & $0.09 \pm 0.17$ & \\
\hline
\end{tabular}

Table 3. Typical evaluations of negative and not identified communications.

\begin{tabular}{ccccc} 
& Social behaviors & Provided work & Not identified & P \\
\cline { 2 - 4 } & $\mathrm{X} \pm$ AND & $\mathrm{X} \pm$ AND & $\mathrm{X} \pm$ AND & $(<0.001)$ \\
\hline $\begin{array}{c}\text { Types of } \\
\text { communication }\end{array}$ & $5.60 \pm 1.64$ & $5.94 \pm 2.57$ & $14.72 \pm 6.21$ & \\
\hline
\end{tabular}

(56.45 \pm 8.55 versus $20.41 \pm 4.11$; $\mathrm{p}<0.001$ ) making recourse to a style of teaching mainly supporting the authority. This can be explained by the fact why teacher nourishes the physical needs for the pupils and rather tends to block the expression of the pupils for a non-autodetermined motivation. Beyond all the considerations, the results obtained in Table 2 showed a highly significant difference between the interactions relating to congratulations, encouragements and criticisms $(F(1,230)=66.20$; $p<0.001)$. In spite of the existence of other forms of expression of the SPT teacher, the encouragements and the congratulations seem to be the natural forms of interaction. It is plausible to criticize, encourage and congratulate pupils who take part in the situations of training. To criticize, encourage and congratulate are undoubtedly catalysts of the investment and on the basis of the degree of the SPT pupils' implication. Griffin (1980) [9] showed that the SPT teachers interact more with boys in the form of organizational feedback. For this purpose, they criticize their behavior, their driving performance and technical information. On the contrary, these teachers congratulate girls with resulting from their performance. The reading of the results of Table 3 indicated a highly significant difference to us between the types in communications $(\mathrm{F}(1,120)=26.12$; $\mathrm{p}<0.001)$ of the interactions are not identified $(14.72 \pm 6.21)$ between teacher and pupils. These results are explained by the didactic warden and leaving by the teaching relationship. In this prospect, Morissette and Gingras (1989) [10], using of the theory of the behaviors, support that the social behavior is attached in a state of pleasure or displeasure and corresponds to an elementary emotional provision of approach or avoidance. For this reason, the social behavior and the work provided by the pupil are regarded as an answer or an emotive reaction interns, positive or negative. When this answer is acquired, the social behavior and provided work constitute an interior provision resulting in a stable, favorable or unfavourable reaction, with respect to the negative communications. In other words, Potvin and Rousseau [11] teach us that the negative communications are defined like a kind of system stable of positive or negative evaluations.

\section{Conclusion}

The results obtained show a broad knowledge of the relationships which are established between the behaviors controlling the SPT teacher and the feedbacks of the pupils. Also, these results confirm on the one hand the highly significant bond between the teachers' authority and the pupils' motivation and reveal on the other hand the considerable need for autonomy through perceptions of the pupils. In this prospect, Morissette and Gingras 
[10], using behaviorist theory, support that the social behavior is attached in a state of pleasure or displeasure and corresponds to an elementary emotional provision of approach or avoidance. For this reason, social behavior and work provided by pupil are regarded as an answer or an emotive reaction, positive or negative interns. When this answer is acquired, the social behavior and provided work constitute an interior provision resulting in a stable, favorable or unfavorable reaction, towards the negative communications. In other words, Potvin and Rousseau [11] teach us that the negative communications are defined like a kind of stable system of positive or negative evaluations.

\section{References}

[1] Brophy, J. and Good, T. (1974) Teacher-Student Relationships: Causes and Consequences. Holt, Rinehart \& Winston, New York.

[2] Potvin, P. and Butterfly, S. (1993) The Causes for Dropping out of School/Las caused bandono escolar. XXIIIe Inter American Congress off Psychology, Santiago (Summarized Published).

[3] Staats, A.W. (1975) Social Behaviorism. Dorsey Near, Homewood.

[4] Good, T.L. and Brophy, J.E. (2000) Looking in Classrooms. 8th Edition, Longman, New York.

[5] Desrosiers, P., Godbout, P. and Spallanzani, C. (1988) Feedback Emitted by a Teacher and Pupils of the Primary Education in Three Strategies of Formative Evaluation: A Case Study. STAPS, 9, 77-84.

[6] Carlier, G., Fox, J.P. and Swalus, P. (1991) Feedback in the Course of Training of Driving Tasks and Their Perception by the Pupils. STAPS, 24, 23-35.

[7] Reeve, J. (2002) Coil-Determination Theory Applied to Educational Setting. In Deci, E.L. and Ryan, R.M., Eds., Handbook of Coil-Determination Research, University of Rochester Near, Rochester, 183-203.

[8] Deci, E.L. (1975) Intrinsic Motivation. Plenum Near, New York.

[9] Griffin, P.S. (1980) Developing Has Systematic Observation Instrument to Identify Sex Role Depend and Sex Role Independent Behavior among Physical Education Teachers. Doctoral Unpublished Essay, University of Massachusetts, New England Boston.

[10] Morissette, R. and Gingras, S. (1989) To Teach Attitudes? To Plan. To Intervene. To Evaluate. Presses of the Laval University, Quebec.

[11] Potvin, P. and Rousseau, J.M. (1991) Reciprocal Attitudes of the Teachers and the Students in Difficulty School. Research Report Subsidized by FCAR (EQ-3562), University of Canada with Three-Rivers. 